This item was submitted to Loughborough's Research Repository by the author.

Items in Figshare are protected by copyright, with all rights reserved, unless otherwise indicated.

\title{
Modification of tricine-SDS-PAGE for online and offline analysis of phosphoproteins by ICP-MS
}

PLEASE CITE THE PUBLISHED VERSION

http://dx.doi.org/10.1007/s00216-010-3588-9

PUBLISHER

(C) Springer

VERSION

AM (Accepted Manuscript)

LICENCE

CC BY-NC-ND 4.0

\section{REPOSITORY RECORD}

Haider, Syed R., Helen J. Reid, and Barry L. Sharp. 2019. "Modification of Tricine-sds-page for Online and Offline Analysis of Phosphoproteins by ICP-MS". figshare. https://hdl.handle.net/2134/13513. 
This item was submitted to Loughborough's Institutional Repository (https://dspace.lboro.ac.uk/) by the author and is made available under the following Creative Commons Licence conditions.

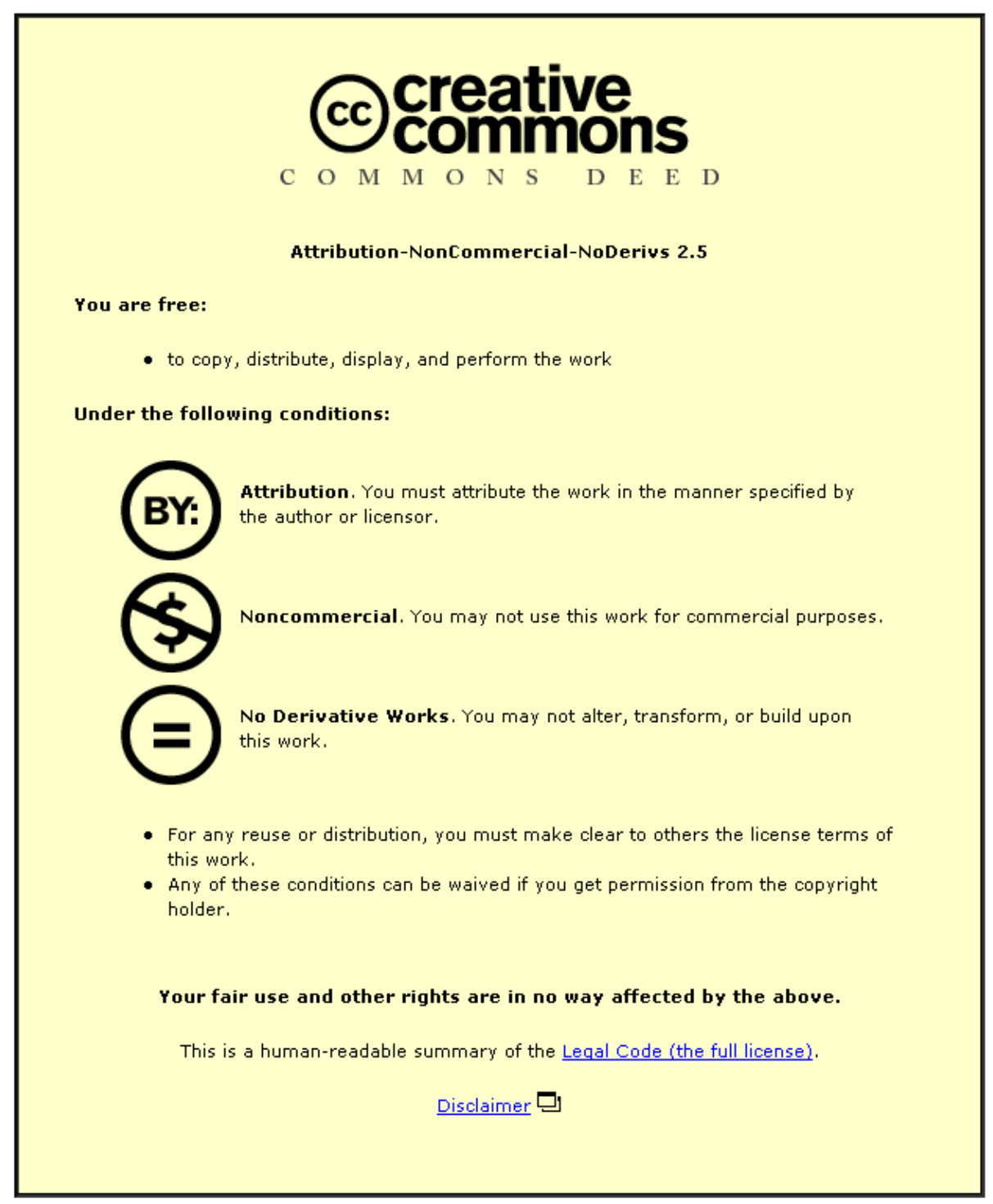

For the full text of this licence, please go to: http://creativecommons.org/licenses/by-nc-nd/2.5/ 


\title{
Modification of Tricine-SDS-PAGE for On-line and Off-line Analysis of Phosphoproteins by ICP-MS
}

\author{
Syed R. Haider, Helen Reid and Barry Sharp* \\ Centre for Analytical Science, Department of Chemistry, Loughborough \\ University, Leicestershire, UK, LE11 3TU, UK. \\ * e-mail: b.l.sharp@lboro.ac.uk
}

\begin{abstract}
This study describes a modification to Tricine-SDS-PAGE to make it more effective for the separation of low molecular mass proteins and for coupling to inductively-coupled plasma mass spectrometry (ICP-MS). The modified method employs low percentage polyacrylamide gels $(7-10 \%)(\mathrm{w} / \mathrm{v})$ and low reagent concentrations that provide efficient separations, good quantitation and low matrix levels that are compatible with ICP-MS. Using phosphopeptides as a model system, and off-line analysis, recoveries of $73 \%(\mathrm{w} / \mathrm{v})$ were obtained in a $9 \% \mathrm{gel}$ compared with $55 \%$ in a conventional $16 \%$ gel. On-line coupling was achieved by modification of a standard commercially available gel electroelution apparatus and casting of the gel into a $7.3 \mathrm{~cm}$ long tube. On-line separation of a digest of $\beta$-casein was demonstrated with recovery of the mono- and tetra-phosphopeptides that were identified by comparison with peptide standards. A mass balance study with the standards yielded recoveries of $95 \%$ for tetraphosphopeptides and $48 \%$ for mono-phosphopeptide. The factors affecting the separations and recoveries are discussed in detail. The detection limits for $10 \mu \mathrm{L}$ samples of the monoand tetra-phosphopeptides were $0.7 \mu \mathrm{M}(7 \mathrm{pmol})$ and $0.2 \mu \mathrm{M}(2 \mathrm{pmol})$ respectively.
\end{abstract}

Keywords ICP-MS, Tricine-SDS-PAGE, Phosphopeptide, Quantification, On-line coupling, Gel percentage

\section{Introduction}

Reversible protein phosphorylation is a key event in the post-translational regulation of cells that alters the shape and functions of proteins and involves a wide range of cellular activities such as cell cycle, differentiation, apoptosis, metabolism and the cell growth division [1]. An abnormal phosphorylation may be a factor in several neurodegenerative disorders leading to Alzheimer's, Parkinson's and Huntington's diseases [2-3]. Thus there is much interest in obtaining qualitative and quantitative information about phosphorylation. 
ICP-MS, when coupled to an appropriate separation technique, is a very sensitive and selective detector for identifying and quantifying low and high molecular mass bio-molecules. Quantitation performed by ICP-MS has several advantages: (a) ICP-MS can detect the analyte of interest at very low concentration, (b) mass balance can be established because the response is independent of structure and (c) calibration is straightforward usually being carried out with inorganic salts. In quantitative phosphoproteomics, the use of ICP-MS provides a different approach compared to more traditional methods. The phosphorus to sulphur (P/S) ratio can be experimentally determined and converted into the degree of phosphorylation using the information available from the sequence [4-6], but a major drawback is that it only applies to those phosphoproteins containing methionine (Met) and cysteine (Cys) residues (sulphur containing amino acids) [6]. Wind et al. reported that any peptide sequence exceeding 20 amino acids in length can be expected to have at least one Met or Cys residue [7]. However, several phosphorylated peptides, such as the tetraphosphopeptides obtained from the tryptic digestion of $\beta$-casein, have a polypeptide sequence of more than 20 amino acids, but do not contain these residues [8] and are therefore outside the scope of this methodology.

The classical strategy for the determination of the specific sites of phosphorylation is the enzymatic digestion of the proteins followed by ESI-MS or MALDI-TOF analysis of the protein fractions. ICP-MS has several advantages over molecular MS, but the separation of the phosphopeptides from other phosphorylated or non-phosphorylated peptides, prior to their identification either by molecular MS or ICP-MS, is essential and has been discussed in detail in several literature reviews [9-11]. In the last few decades, several on-line and off-line separation techniques have been used for protein separation such as immobilized metal affinity chromatography (IMAC) [12], reversed phase chromatography [13], size exclusion chromatography (SEC) [14], capillary zone electrophoresis (CZE) [15] etc. However, Slab GE remains a bench mark for protein analysis and is the most widely used because of its high reproducibility and resolving power. The major advantages of using slab GE methods are: (a) molecular weight determination of unknown proteins is accomplished easily using mass standards, (b) low to high molecular weight proteins can be separated in a single gel and (c) a number of protein samples, including standards, can be run simultaneously in a single gel under identical conditions and can be compared using the band patterns.

For obtaining enhanced quantitative information, a low percent gel is ideal because (a) the analyte can be transferred more effectively onto a membrane during the electroblotting procedure, particularly those proteins with a high molecular mass and hydrophobic character which do not properly transfer using high percentage acrylamide gels and show poor recovery [16]; (b) Laser Ablation (LA)-ICP-MS can be performed effectively directly on the gel; (c) a lower voltage and shorter time is required for separation and electroelution so there is less 
chance of degrading the phosphorus-containing molecules with consequent band distortion [17].

Tris-glycine or Laemmli [18] SDS-PAGE is one of the most widely used methods for the electrophoretic separation of proteins. However, this method has very poor resolving efficiency for separating 1-30 $\mathrm{kDa}$ proteins in a low percentage polyacrylamide gel [16]. Therefore, in order to resolve low mass proteins in a low percentage gel, several modifications of this system have been reported. One way is decreasing the pore size of the gel [19-20] by increasing the cross-linking $(\% \mathrm{C})$ or by adding urea to the gel [17, 21]. However by adding a greater quantity of the cross-linker, the gel becomes more brittle. The addition of urea is useful for the analysis of low mass proteins, but it crystallizes at low temperature and sometimes decomposes during sample preparation [22]. Urea can also modify proteins by forming a carbamoylate derivative of lysine and other residues [23]. Another possible modification is the use of gradient gels [24], which provide good separation of low mass proteins, but they also have several deficiencies including irreproducibility of separation (especially in mini-gels), a time consuming cast, a tendency to break during the run, and they are difficult to store [22]. Moreover, they are not good for resolving peptides lower than 10 $\mathrm{kDa}[17]$.

In another development, Schägger and von Jagow [24] introduced the Tricine-SDS-PAGE method. Compared with glycine, tricine migrates much faster in a stacking gel at usual $\mathrm{pH}$ values and shifts the stacking limit from high to low molecular mass range proteins, which allows good separation of the smaller SDS-peptide complexes [17]. Tricine-SDS-PAGE is a further improvement because it enables the separation of low mass proteins in a lowpercentage polyacrylamide gel. Usually, a $10 \%$ gel (with $\mathrm{pH} 8.45$ ) in Tricine-SDS-PAGE can separate proteins in the range of $1-100 \mathrm{kDa}$ using two running buffers: a cathode buffer e.g. $100 \mathrm{mM}$ Tris, $100 \mathrm{mM}$ tricine and 0.1\% (w/v) SDS, pH 8.25, in the cathode chamber and an anode buffer e.g.100 mM Tris, pH 8.9, in the anode chamber. However, to obtain highly resolved bands, this method needs three gels (stacking, spacer and resolving gel) [16, 24-25] and addition of urea [16] in the resolving gel. The use of three gels is tedious, potentially troublesome and requires a freshly prepared gel mixture [25]. Addition of the urea may also create problems in amino acid sequencing [17].

The coupling of separation techniques to ICP-MS, such as capillary gel electrophoresis (CGE) [26], GE-LA [27-29] and micro liquid chromatography $(\mu \mathrm{LC})$ [4, 30-31] were important developments in proteomics and genomics studies. The $\mu$ LC-ICP-MS (pioneering work described by Lehmann and co-workers [32] for phosphopeptide analysis) is a selective and a very powerful approach for the detection and quantification of phosphopeptides. The system has a number of advantages over other separation techniques: (a) smaller ID columns 
require low flow rates $\left(\mu \mathrm{L} \min ^{-1}\right.$ or $\mathrm{nL} \min ^{-1}$ ) which provide positive economic and environmental benefits and help to overcome the organic solvent problem in ICP-MS analysis [33] yielding solvent compatibility with the ICP, low backgrounds and good resolution; and (b) sensitivity is improved and a reduced amount of the analytical sample is needed. On the other hand, there are drawbacks of using $\mu$ LC-ICP-MS such as: (a) the low flow rates limit the choice of the nebulizer and spray; (b) miniaturization may reduce robustness of the system [34]; and (c) it may not be very useful in analyzing large bio-molecules.

The recently introduced on-line coupling of GE to ICP-MS is a further development and was first described by Brüchert and Bettmer [35] for the determination of dsDNA fragments. More recently, it has been reported for several applications including: size characterization of gold nano particles [36], detection of iron in metalloproteins [37], determination of the degree of phosphorylation in casein [38], and for iodide and iodate determination in aerosols [39]. However, there appear to be no previous reports of this technique being applied to phosphopeptide analysis. GE-ICP-MS coupling also enjoys a wide range of benefits over the conventional RP-LC-ICP-MS technique including: (a) the cost of the gel is much cheaper than the cost of the column used in LC-ICP-MS and is readily replaceable in case of damage; (b) the flow rate is flexible $\left(\mu \mathrm{L} \mathrm{min}^{-1}\right.$ to $\mathrm{mL} \mathrm{min}^{-1}$ ) and conventional nebulizers are usually satisfactory; (c) non-volatile buffers used are more tolerable than the volatile buffers used in most RP-HPLC-ICP-MS separations; and (d) a wider range of sizes of bio-molecules can be analyzed. This approach also has some limitations and further investigation is required to overcome them, e.g. (a) broader peaks are obtained than for $\mu$ LC-ICP-MS; (b) protein/peptides can be fragmented into the gel; (c) contamination from the gel and buffers may cause poor detection limits; and (d) acrylamide/bis-acrylamide is a neurotoxin and suspected carcinogen so extra care is required when using these gels. Whilst it is possible to compare in an absolute sense the merits of GE and LC methods, in practice they are not competitive, but complementary. GE is usually used for prospective analysis and is then followed by LC after a sub-set of analytes has been identified and purified.

The main objectives of this study were (a) to develop a simplified GE method employing low percentage gels and low reagent concentration Tricine-SDS-PAGE system for the separation of peptides and proteins (b) to use this modified system to enhance the quantitation of phosphopeptides/phosphoproteins in off-line and on-line coupling analysis with ICP-MS. In GE-ICP-MS on-line coupling, the protein of interest can be eluted for detection by ICP-MS by adopting one of two strategies: (a) using running buffer as the elution buffer or (b) using an elution buffer from a separate buffer chamber. Both strategies are effective and purely depend on the instrumentation used. Here, the first strategy was employed as it is simple and required less modification to the original gel separation unit. 


\section{Experimental}

\section{Chemicals}

The following chemicals were purchased from Sigma-Aldrich, Poole, Dorset, United Kingdom. Anionic detergent SDS and ultra-pure tricine as the components of the running buffer; $\alpha$ and $\beta$-casein as model proteins; $30 \%(w / v)$ solution of acrylamide/bis-acrylamide (29:1) for the preparation of the polyacrylamide gel; ultra-pure tris (hydroxymethyl)-amino methane (Tris) for the preparation of the buffer solutions; $N, N, N^{\prime}, N^{\prime}$ - tetramethylethylenediamine (TEMED) to catalyse the polymerization reaction, ammonium persulphate (APS) to initiate the polymerization reaction; $2 \mathrm{x}$ sample buffer to prepare the protein sample before loading onto the gel; 1,4-dithio-DL-threitol (DTT) as a reducing agent, iodoacetamide (IAA) as an alkylating agent and ammonium bicarbonate $\left(\mathrm{NH}_{4} \mathrm{HCO}_{3}\right)$ as a buffer for protein digestion; Coomassie Brilliant Blue to prepare the staining solution and as a protein tracking dye and $25 \%(\mathrm{v} / \mathrm{v})$ glutaraldehyde solution for fixing the proteins in the gel. Sequencing grade modified trypsin for the digestion of $\beta$-casein was purchased from Promega Corporation UK.

All the solutions were prepared in ultra-pure water (18 M- $\Omega$, from a Milli-Q water purification system, Millipore Corporation, Bedford, MA).

\section{Protein standards}

A protein standard (1) with a mass range of 2.5-200 kDa was purchased from Invitrogen Corporation UK. Ultra-Low Range Molecular Weight Marker ${ }^{\mathrm{TM}}$ (2) with a range of 1-26.6 kDa was purchased from Sigma Aldrich UK. The detail of these protein standards is described in Table 1. Mono- [T6 (1P)] and tetra- $[\mathrm{T} 1-2(4 \mathrm{P})]$ phosphopeptide standards $[(\mathrm{M}+\mathrm{H})=2061.8$ and 3122.2 respectively] were also purchased from Sigma Aldrich UK.

\section{Protein digestion}

Protein digestion in solution for a comparative study was performed according to the following method. $10 \mu \mathrm{L}$ of $1 \mathrm{mg} / \mathrm{mL} \beta$-casein solution was dissolved in $15 \mu \mathrm{L}$ of $50 \mathrm{mM} \mathrm{NH}_{4} \mathrm{HCO}_{3}$ and $1.5 \mu \mathrm{L}$ of $100 \mathrm{mM}$ DTT solution and incubated at $90{ }^{\circ} \mathrm{C}$ for $5-10 \mathrm{~min}$. After cooling to room temperature, $3 \mu \mathrm{L}$ of $100 \mathrm{mM}$ IAA was added to this solution and incubated for 25 minutes in the dark. $1 \mu \mathrm{L}$ of $0.1 \mu \mathrm{g} / \mu \mathrm{L}$ sequencing grade modified trypsin was then added and incubated at $37^{\circ} \mathrm{C}$ for 4 hours. Finally, an additional $1 \mu \mathrm{L}$ of this trypsin was added and incubated overnight at $30^{\circ} \mathrm{C}$. Next day, the digest mixture was dried to $10 \mu \mathrm{L}$ using vacuum. 


\section{Tricine-SDS-PAGE}

\section{Buffer system}

To prepare the stacking and resolving gels, $2.5 \mathrm{M}$ Tris-buffer with a pH of 8.8 for the modified system and with a $\mathrm{pH}$ of 8.45 for the conventional system was prepared. The $\mathrm{pH}$ of the gel buffers were adjusted using $\mathrm{HCl}$. Running buffers with $25 \mathrm{mM}$ concentration of Tris-tricine and $0.05 \%$ SDS for the modified method and $100 \mathrm{mM}$ Tris-tricine and $0.1 \%$ SDS for the original method were prepared. (Note: only one running buffer was employed in both methods).

$2 \mathrm{x}$ sample buffer was purchased from Sigma Aldrich, containing $100 \mathrm{mM}$ Tris- $\mathrm{HCl}(\mathrm{pH} \mathrm{6.8})$, $1 \%(\mathrm{w} / \mathrm{v})$ SDS, $4 \%(\mathrm{v} / \mathrm{v})$ 2-mercaptoethanol, $0.02 \%(\mathrm{w} / \mathrm{v})$ Coomassie Brilliant Blue and $24 \%$ $(w / v)$ glycerol.

\section{Sample preparation}

For the slab gels, $10 \mu \mathrm{L}$ of the sample buffer were mixed with (a) $10 \mu \mathrm{L}$ of $1 \mathrm{mg} / \mathrm{mL} \beta$-casein and (b) $10 \mu \mathrm{L}$ of the digest mixture. For on-line coupling, $10 \mu \mathrm{L}$ of the sample buffer were mixed with one of the following: (a) $10 \mu \mathrm{L}$ of the digest mixture, (b) $10 \mu \mathrm{L} \alpha$ - and $\beta$-casein (final concentration $0.10 \mathrm{nM}$ each), or (c) $10 \mu \mathrm{L}$ mixture of mono and tetra-phosphopeptide standards giving final concentrations of $20.2 \mu \mathrm{M}$ of [T6 (1P)] and $16.3 \mu \mathrm{M}$ of [T1-2 (4P)].

\section{Gel casting}

Stacking and resolving gels were cast for both the modified and original method as described in Table 2. Urea, SDS and glycerol were not included in any of the gels. For slab gels, a minigel casting apparatus was purchased from Bio-Rad UK (Mini-PROTEAN ${ }^{\circledR} 3$ Cell) and all the gels were cast at $7.3 \mathrm{~cm}$ height $\times 8 \mathrm{~cm}$ width and $0.75 \mathrm{~mm}$ thickness. (Note: acrylamide is recognised as a neurotoxin, so gloves must be worn all the time and the work must be done in a properly ventilated area). For on-line coupling (see Instrumentation section), 10, 10.5 and $15 \%$ tube gels were also cast in a similar manner within a length of $7.3 \mathrm{~cm}$ and $1 \mathrm{~cm}$ internal diameter (ID) in a borosilicate glass tube. 


\section{Protein Loading}

$7 \mu \mathrm{L}$ of protein standard (1) and $5 \mu \mathrm{L}$ of protein standard (2) were injected onto the slab gels. Similarly, $10 \mu \mathrm{L}$ of $\beta$-casein solution for the mass balance study (by off-line analysis), and 10 $\mu \mathrm{L}$ of the digest mixture were also loaded onto the slab gels. $10 \mu \mathrm{L}$ of each of the mixtures of: $0.10 \mathrm{nM} \alpha$-casein and $\beta$-casein, the digest mixture of $\beta$-casein, and 20.2 and $16.3 \mu \mathrm{M}$ mixture of [T6 (1P)] and [T1-2 (4P)] respectively were injected into the tube gel for on-line coupling.

\section{Gel fixing, staining and destaining}

A fixing solution of $5 \%(\mathrm{v} / \mathrm{v})$ glutaraldehyde was prepared and each slab gel was fixed for 25 minutes. A $0.025 \%(\mathrm{w} / \mathrm{v})$ Coomassie Brilliant Blue solution was prepared in $10 \%(\mathrm{v} / \mathrm{v})$ acetic acid and each gel was stained for 20 minutes after washing with deionised water. For sharp bands, the staining was repeated by replenishing the staining solution. Gels were washed with deionized water and destaining was performed using $10 \%$ acetic acid for 15-20 minutes.

\section{Whole Gel Elution (WGE) for off-line analysis}

$\beta$-casein $(10 \mu \mathrm{g})$ was electrophoretically run through $9 \%$ and $16 \%$ modified slab gels. The tracks containing the protein bands were then cut from the gels using a sharp blade. These individual tracks ( $9 \%$ and $16 \%$ gels) were loaded into the electroeluter glass tubes separately and electroeluted using the Bio-Rad 422 electroeluter. Tricine-SDS-PAGE modified running buffer was used as an elution buffer for 2 hours at 0.01-0.02 A current applied to each tube. A blank gel of each of the 9 and $16 \%$ gels was also electroeluted following the same procedure to subtract the background signal intensity of the ${ }^{31} \mathrm{P}$. WGE was also performed for phosphorylated peptide band detection. Briefly, the $\beta$-casein digest $(10 \mu \mathrm{L})$ was injected into a $10 \%$ slab gel. After Coomassie staining each band was cut to equal size and electroeluted for 2.5 hours by applying a 0.01-0.02 A current per tube. A blank gel was also electroeluted for the control.

Instrumentation

GE-ICP-MS on-line coupling 
A schematic diagram of the GE-ICP-MS on-line coupling is shown in Fig. 1. For this coupling, a Model 422 Electroeluter GE system was purchased from Bio-Rad UK. This electroeluter included a borosilicate glass tube of $1 \mathrm{~cm} I D \times 6 \mathrm{~cm}$ length, but here this original elution tube was replaced by a glass tube of $1 \mathrm{~cm} I D \times 7.3 \mathrm{~cm}$ length into which a capillary tube of the same length, with an ID of $1 \mathrm{~mm}$ was placed. Gels were cast into the outer tube $(1 \mathrm{~cm} I D)$ and the capillary was used for pumping the buffer and eluted proteins to the ICP-MS nebulizer. (It is important to note that this inset capillary did not show any negative effect on separation. As stated above, a focus in this work was to minimize modification of the original device. Thus the capillary was taken from the upper reservoir, rather than a separate one, and this helped to balance the pressure and prevented displacement of the dialysis membrane). At the bottom end of the tube, a porous polypropylene frit was placed to filter the running buffer and reduce further the SDS concentration before introduction to the ICP-MS instrument. This tube was then placed into a silicone adapter with the outlet connected directly to a peristaltic pump via Teflon tubing. The other end of the pump was connected to an ICP-MS nebuliser. A dialysis membrane, made in-house with a molecular mass cut-off of $\sim 1.5 \mathrm{kDa}$, was placed at the bottom end of the adapter to connect the electrodes to the buffer reservoirs. The total inner dead volume between polypropylene frit and dialysis membrane was only about $20 \mu \mathrm{L}$. The upper (cathode) and lower (anode) buffer chambers were filled with $200 \mathrm{~mL}$ and $600 \mathrm{~mL}$ of the running buffer respectively. The separation was carried out at $0.03 \mathrm{~A}$ current at a voltage of 80-90 V. When the dye front reached the bottom of the tube, the running buffer (from upper buffer chamber) was then pumped towards the nebulizer with a flow rate of $130 \mu \mathrm{L} \mathrm{min}^{-1}$ via the inset capillary tube until the proteins of interest were eluted. The current applied during this time was 0.04-0.05 A (150-200 V). The GE parameters are listed in Table 3.

\section{ICP-MS}

ICP-MS analysis for ${ }^{31} \mathrm{P}$ was performed on an Element 2 XR Sector Field ICP-MS instrument (Thermo Finnigan Corporation, Bremen, Germany). The instrument was operated at medium resolution $(R=4000)$ to avoid interferences on the ${ }^{31} \mathrm{P}$ signal at $\mathrm{m} / \mathrm{z}=30.973 \mathrm{u}$ from ${ }^{15} \mathrm{~N}^{16} \mathrm{O}$ $(\mathrm{m} / \mathrm{z}=30.999 \mathrm{u})$ and ${ }^{14} \mathrm{~N}^{16} \mathrm{O}^{1} \mathrm{H}(\mathrm{m} / \mathrm{z}=31.005 \mathrm{u})$ signals. ICP-MS parameters are given in Table 4 . 


\section{Results and discussion}

\section{Modified Tricine-SDS-PAGE method}

To increase the compatibility of the Tricine-SDS-PAGE system with ICP-MS, changes were made to the original method, decreasing the component concentrations of the running buffer and altering the $\mathrm{pH}$ of the gel buffer. Separations achieved on the slab gel by employing two different protein mass ladders are shown in Fig. 2. The effects of the modification are discussed in detail below.

\section{Effect of changing the running buffer concentration}

An important step in coupling ICP-MS to separation techniques is to optimize mobile phase composition. For example, organic buffers, which contain a high concentration of carbon have several adverse effects on ICP-MS such as: (a) build up of carbon deposition leads to clogging of the interface cones and injector of the torch and, as a result, decreases the sensitivity of the ICP-MS instrument [40-42]; (b) a high level of carbon generates a number of polyatomic carbon based interferences for e.g., $\mathrm{C}_{2}^{+}, \mathrm{CNH}^{+}, \mathrm{CO}_{2}{ }^{+}$and ${ }^{38} \mathrm{Ar}^{13} \mathrm{C}^{+}$for $\mathrm{Mg}^{+}, \mathrm{Al}^{+}$, $\mathrm{Ca}^{+}$and $\mathrm{V}^{+}$respectively; and (c) volatile buffers increase plasma loading and may cause destabilization of the plasma. To use a high carbon concentration, it is usual to add oxygen to the nebulizer gas [40-42], however, the addition of oxygen may reduce cone life [43]. Nonvolatile buffers are better tolerated than volatile ones. However, where possible, low buffer concentrations are preferable, there are no negative effects and contamination is reduced which is important for ubiquitous elements such as phosphorus. For Tris-HCl Lobinski et al. reported up to $30 \mathrm{mM}$ concentration is well tolerated by ICP-MS [44].

Tricine-SDS-PAGE running buffer in the original method contains $100 \mathrm{mM}$ Tris, $100 \mathrm{mM}$ tricine and $0.1 \%$ SDS with the gel buffer $\mathrm{pH}$ at 8.45 . It was found that by reducing this running buffer concentration down to $25 \mathrm{mM}$ Tris, $25 \mathrm{mM}$ tricine and $0.05 \%$ SDS and increasing the $\mathrm{pH}$ of the gel buffer to 8.8 there was no negative effect on the band resolution. Comparative results for the digest mixture of the $\beta$-casein were obtained after running the tricine original and modified SDS-PAGE method with the $10 \%$ gels as shown in Fig. 3 . The molecular mass values of the bands were calculated using the protein ladder. The serine (S) residues of the amino acid sequence of $\beta$-casein are phosphorylated at positions 30, 32-34 and 50 (Swiss Prot). Trypsin cleaves the amino acid sequence from arginine $(R)$ and lysine $(K)$ residues and gives the two phosphorylated fragments i.e., a mono-phosphopeptide $[(M+H)=2061.8]$ and a tetra-phosphopeptide $[(\mathrm{M}+\mathrm{H})=2966.16]$ with the sequences FQ-Sp-EEQQQTEDELQDK 
and ELEELNVPGEIVE-Sp-L-SpSpSp-EESITR respectively. Two further tetraphosphopeptides from $\beta$-casein digest i.e., $[\mathrm{M}+\mathrm{H}=2352.85]$ NVPGEIVE-Sp-LSpSpSpEESITR and [M+H = 3122.27] RELEELNVPGEIVE-Sp-L-SpSpSp-EESITR were also reported $[8,45]$. These phosphopeptides are usually obtained because of the mis-cleavages or chemotryptic activities of the trypsin enzyme [8]. It was previously reported that the molecular masses of phosphorylated peptides could not be determined in SDS-PAGE [17] as they do not properly form micelles with the SDS and therefore migrate slower. For the identification of the phosphorylated bands, WGE of each digested band was performed and $10 \mu \mathrm{L}$ of each fraction was introduced to the ICP-MS instrument by flow injection using the modified running buffer stream. The ${ }^{31} \mathrm{P}$ area of each peak was calculated and the bands containing the phosphopeptides were identified in the gel as the only peptide bands with $a^{31} \mathrm{P}$ peak area above the blank (Fig. 3). However, these bands were not well resolved most likely due to several peptide impurities. The ${ }^{31} \mathrm{P}$ peak area of each band is listed in Table 5.

\section{Effect of changing the $\mathrm{pH}$ of the gel buffer}

In a gel electrophoresis procedure, the $\mathrm{pH}$ of the resolving gel plays an important role in protein separation. The effect of changing $\mathrm{pH}$ in a classical Laemmli system has been reported previously [46] and it was stated that by increasing the $\mathrm{pH}$ of the resolving gel, a slightly lower molecular mass band could be observed in a 10\% gel. In an SDS-PAGE system a high $\mathrm{pH}$ in the separating gel is not only helpful in resolving the proteins, but it also increases the protein (wrapped with SDS) mobility in the gel and results in a low current that reduces heat generation. For quantitation, a low temperature in the gel is more likely to maximise the recovery of the proteins. The $\mathrm{pH}$ of the stacking and resolving gels is adjusted to 8.45 in conventional Tricine SDS-PAGE system. Here, it was shown that by increasing the $\mathrm{pH}$ of the resolving and stacking gels up to 8.8, the band resolution and separation of peptides/proteins was not degraded. By increasing the $\mathrm{pH}$ an additional band was observed in the 7, 9 and $10 \%$ gels (Fig. 4) compared to the original method. In previous studies $1-100$ $\mathrm{kDa}$ protein separation has been claimed in a $10 \%$ gel using the original method [16-17, 24]. This necessitated the use of two running buffers, urea, a three gel system or an increase in the cross linking to achieve such level of separation employing the original method. Hence increasing the $\mathrm{pH}$ up to 8.8 makes the system much easier and low molecular mass peptides separation was observed in 7,9 and $10 \%$ polyacrylamide gels using a simplified procedure. 


\section{Off-line analysis for recovery studies}

In order to check the efficiency of the low and high percentage gels for protein recovery a mass balance study was carried out using WGE followed by ICP-MS. The total percentage recovery of the ${ }^{31} \mathrm{P}$ was calculated as $73 \pm 2.1 \%$ and $55 \pm 1.6 \%(N=3)$ (after 2 hours electroelution) from the $9 \%$ and $16 \%$ gels respectively. Thus the quantitative recovery of the $\beta$-casein in the low percentage gel was shown to be higher. The major factors that may affect the recovery using high percentage gels are: (a) a high percentage gel increases the electrical resistance leading to more heat generation - this heat develops a temperature gradient from the centre of the gel to the gel surface due to the uneven heat loss and causes distorted bands [17]; and (b) a high percentage polyacrylamide gel increases the run time and running the sample for too long may cause protein fragmentation. These factors show that a high percentage gel is not an ideal choice to recover the maximum quantity of the protein from the gel.

\section{GE-ICP-MS on-line coupling}

A focus of this study was to investigate the efficiency of the modified Tricine-SDS-PAGE method for on-line coupling to ICP-MS. Previously described GE-ICP-MS on-line systems used a separate elution buffer from a separate buffer chamber and therefore require detailed modification of the system. The decrease in the running buffer concentration provides an additional benefit as it can be used as an elution buffer in the modified system. $200 \mathrm{~mL}$ of the running buffer from the upper buffer chamber (coupled to the outlet chamber by the embedded capillary) is enough for many hours running with a flow rate of $130 \mu \mathrm{L} \mathrm{min.} .^{-1}$

The initial testing of the effectiveness of this on-line system was performed by the successful online separation of a mixture of $\alpha$-casein $(22.97 \mathrm{kDa})$ and $\beta$-casein $(23.58 \mathrm{kDa})$, as shown in Fig. 5 . Very good signals were recorded at $0.10 \mathrm{nM}$ concentration of each of $\alpha$ - and $\beta$-casein. The degrees of phosphorylation on $\alpha$-casein and $\beta$-casein were reported previously as 9.1 and 4.9 respectively $[4,38]$. Therefore, enhanced ${ }^{31} \mathrm{P}$ signal intensity of the first peak was observed compared to the second one, however the ${ }^{31} \mathrm{P}$ signal intensity of $\beta$-casein was lower than expected as it was found to be contaminated with several proteins including $\alpha$-casein, which was further enhancing the a-casein signal intensity (Fig. 5). The resolution was sufficient and after elution of the protein the ${ }^{31} \mathrm{P}$ signals quickly reached the base line, which is an indication of a very low memory effect, although a slight tailing was still observed. 
The role of the running buffer is important not only in protein separation, but also in GE-ICPMS coupling for peak shape, elution time, detection and quantification limits of the analytes, especially when it is also used as an elution buffer. The results show good peak shape and very low background signals. In a comparative study it was observed that the ${ }^{31} \mathrm{P}$ buffer background signals of the modified system were 2 to 3 times lower than the original method. This indicates that an enhanced phosphopeptides detection limit can be achieved using this modified system. A blank sample was run using a $10 \%$ gel for the control measurement in the modified system and no ${ }^{31} \mathrm{P}$ peak was observed. The use of SDS limits this system to identifying elements other than $S$, thus the $P / S$ ratio for $\alpha$ - and $\beta$-casein could not be determined here.

For the separation of mono- and tetra-phosphopeptides from the $\beta$-casein digest, initially a $10 \%$ gel was employed to resolve the phosphorylated peaks (Fig. 6), but, as there was only one peak observed with comparatively high signal intensity, the gel percentage was gradually increased and a $15 \%$ gel was found to resolve the two ${ }^{31} \mathrm{P}$ peaks (Fig. 7). Further increasing the gel percentage did not show any additional peaks. It was concluded that the mono and tetra-phosphopeptide peaks were not fully resolved (even in the $15 \% \mathrm{gel}$ ) due to the presence of several phosphorylated and non-phosphorylated peptide impurities in the digest. A low percentage $(10 \%)$ tube gel was not able to separate these impurities and as a result all the peptides were eluting as a single unresolved band and one peak was observed in the electropherogram. This was confirmed by running the mixture of [T6 (1P)] and [T1-2 (4P)] respectively (Fig. 8), which were resolved in the $10.5 \%$ gel.

It is important to note that significant peak tailing was observed from the digest mixture (Fig. 6 and 7) so that baseline separation was not achieved. Several contributing factors to peak tailing in the electrophoretic peaks have been discussed in previous studies [47] including overloading of the analytes and weak efficiency of the column. Hence a large number of unresolved ${ }^{31} \mathrm{P}$ peptide impurities were the major likely cause of peak tailing here. The main source for the phosphopeptide impurities could be mis-cleavages during the digestion [8] and $\alpha$-casein contamination [48], which was also digested with the $\beta$-casein. Slow mass transfer to the detector is also an important factor in peak broadening [49]. So by increasing the gel percentage, protein transportation to the ICP-MS slowed down causing broader peaks as shown in Fig. 7.

A mass balance study was carried out using [T6 (1P)] and [T1-2 (4P)] and recoveries of $48 \pm 3.1 \%$ and $95 \pm 4.0 \%(\mathrm{~N}=3)$ respectively were obtained. The cut-off $\sim 1.5 \mathrm{kDa}$ of the dialysis membrane used here may well be the cause of low recovery of [T6 (1P)]. 
Lower limits of detection (LLD) were achieved as 0.7 and $0.2 \mu \mathrm{M}$ for [T6 (1P)] and [T1-2 (4P)] respectively using the criteria of three times the standard deviation of the blank. These correspond to $7 \mathrm{pmol}$ and $2 \mathrm{pmol}$ per $10 \mu \mathrm{L}$ sample of the mono and tetra-phosphopeptide solutions.

\section{Conclusion}

In conclusion, an easy and rapid method for the separation of peptides in low percentage uniform acrylamide gels has been described. This was achieved by modifying the previously described Tricine-SDS-PAGE system. This modified system reduces by 3 to 4 times the cost of the consumables, and using standards, separation with very good resolution was achieved by slab GE. Using low percentage gels and very low reagent concentrations reduced contamination and improved performance for quantitative proteomics and phosphoproteomics. A GE-ICP-MS set-up for the on-line separation of phosphoproteins/phosphopeptides was also investigated using the modified Tricine-SDSPAGE system. Whilst several custom made GE-ICP-MS systems have been described previously, here a setup was employed that required only minor modification of the original commercial electroeluter device. Using the modified Tricine-SDS-PAGE enables elemental detection in proteins/peptides such as those typically found in the tryptic digests of phosphorylated proteins. Here, very low ${ }^{31} \mathrm{P}$ background signals were obtained and yielded good LLD values for the phosphopeptides. However, use of the large format tube gels, limited peak resolution and this approach may not be useful for the detection of several phosphorylated peptides in digest mixtures in comparison with $\mu \mathrm{LC}$-ICP-MS systems. Future studies will investigate the use of smaller diameter tube gels, or slab gels, to improve peak resolution.

\section{References}

1 Graves, J.D. \& Krebs, E.G. Protein phosphorylation and signal transduction.

Pharmacol Ther 82: 111-121 (1999).

2 Buee L, Bussiere T, Buee-Scherrer V, Delacourte A, Hof PR (2000) Brain Research Reviews 33: 95-130

3 Greengard P, Allen PB, Nairn AC (1999) Neuron 23:435-447

4 Wind M, Wesch H, Lehmann WD (2001) Anal Chem 73: 3006-3010

5 Bandura DR, Baranov V, Tanner SD (2002) Anal Chem 74: 1497-1502

6 Pereira-Navaza A, Encinar JR, Carrascal M, Abian J, Sanz-Medel A (2008) Anal Chem 80: 1777-1787 
Wind M, Wegener A, Eisenmenger A, Kellner R, Lehmann WD (2003) Angew Chem Int Ed 42: 3425-3427.

8 Larsen MR, Thingholm TE, Jensen ON, Roepstorff P, Jorgensen TJ (2005) Mol Cell Proteomics 4: 873-886

9 Ammann AA (2007) J Mass Spectrom 42: 419-427

10 Sanz-Medel A, Montes-Bayon M, Fernandaz de la Campa MR, Encinar JR, Bettmer J (2008) Anal Bioanal Chem 390: 3-16

11 Bettmer J, Montes-Bayon M, Encinar JR, Fernandez-Sanchez ML, Fernandaz de la Campa MR, Sanz-Medel A (2009) J Proteom 72: 989-1005

12 Posewitz MC, Tempst P (1999) Anal Chem 71: 2883-2892

13 Hann S, Koellensperger G, Obinger C, Furtmueller PG, Stingeder G (2004) J Anal At Spectrom19: 74

14 Moore JC (1964) J Polym Sci A2: 835

15 Szpunar J, Lobinski R, Prange A (2003) Appl Spectrosc 57: 102-112

16 Schägger $H(2006)$ Nature 1: 16-22

17 Hames BD (1998) Gel Electrophoresis of Proteins Oxford University Press, New York.

18 Laemmli UK (1970) Nature 227: 680-685

19 Takagi T, Kubo K (1979) Biochem Biophys Acta 578: 68-75

20 Anderson BL, Berry RW, Telser A (1983) Anal Biochem 132: 365-375

21 Swank RT, Munkres KD (1971) Anal Biochem 39: 462-477

22 Okajima T, Tanabe T, Yasuda T (1993) Anal Biochem 211: 293-300

23 Bothe D, Simonis M, Dohren H (1985) Anal Biochem 151: 49-54

24 Schägger H, von Jagow G (1987) Anal Biochem 166: 368-379

25 Yim SK, Ahn T, Kim JK, Yun CH (2002) Anal Biochem 305: 27-281

26 Prange A, Pröfrock D (2005) Anal Bioanal Chem 383: 372-389

27 Marshall P, Heudi O, Bains S, Freeman HN, Abou-Shakra, F Reardon K (2002) Analyst 127: 459-461

28 Wind M, Feldmann I, Jakubowski N, Lehmann WD (2003) Electrophoresis 7:1276-1280

29 Raab A, Pioselli B, Munro C, Thomas-Oates J, Feldmann J (2009) Electrophoresis 30: 303-314

30 Wind M, Eisenmenger A, Wesch H, Lehmann WD (2002) J Anal At Spectrom 17: 21-26

31 Ellis J, Del Castillo E, Montes-Bayon M, Grimm R, Clark JF, Pyne-Geithman G, Wilbur S, Caruso JA (2008) J Proteome Res 7: 3747-3754

32 Wind M, Edler M, Jakubowski N, Linscheid M, Wesch H, Lehmann WD (2001) Anal Chem 73: 29-35

33 Weng M, Feng W, Zhao Y, Chai Z, (2009) Mass Spectrometry Reviews DOI $10.1002 /$ mas

34 Czerwenka C, Lämmerhofer M, Lindner W (2003) J Pharm Biomed Anal 30: 17891800 
35 Brüchert W, Bettmer J (2005) J Anal Chem 77: 5072 - 5075

36 Helfrich A, Brüchert W, Bettmer J (2006) J Anal At Spectrom 21: 431-434

37 Anorbe MG, Messerschmidt J, Feldmann I, Jakubowski N (2007) J Anal At Spectrom 22: $917-924$

38 Helfrich A, Bettmer J (2007) J Anal At Spectrom 22: 1296 -1299

39 Brüchert W, Helfrich A, Zinn N, Klimach T, Breckheimer M, Chen H, Lai S, Hoffmann T, Bettmer J (2007) J Anal Chem 79: 1714-1719

40 Sutton KL, Caruso JA (1999) J Cromatogr 856: 243-248

41 Yanes EG, Miller-Ihli NJ (2005) Spectrochimica Acta Part B 60: 555-561

42 Ponce de Leon CA, Montes-Bayon M, Caruso JA (2002) J Chromatogr A 974: 1-21

43 Szpunar J, Lobinski R (1999) Pure Appl Chem 71: 899-918

44 Lobinski R, Chassaigne H, Szpunar J (1998) Talanta 46: 271-289

45 Dong J, Zhou H, Wu R, Ye M, Hanafa Z (2007) J Sep Sci 30: 2917-2920

46 Makowski GS, Ramsby ML (1993) Anal Biochem 212: 283-285

47 Fornstedt T, Zhong G, Guiochon G (1996) J Chromatogr A 741: 1-12

48 Pröfrock D, Prange A (2009) J Chromatogr A 1216: 6706-6715

49 Szantai E, Guttman A (2008) In: Landers JP (ed) In Hand book of Capillary and Microchip Electrophoresis and Associated Microtechniques, 3rd edn. CRC Press, Taylor and Francis Group, New York 
Table 1 Detail of protein standards 1 and 2

\begin{tabular}{|c|c|c|}
\hline Protein standard 1 & Protein standard 2 & $\begin{array}{l}\text { cular mass } \\
\mathrm{kDa}\end{array}$ \\
\hline Myosin & - & 200.0 \\
\hline$\beta$-galactosidase & - & 116.3 \\
\hline Phosphorylase B & - & 97.4 \\
\hline Bovine serum albumin (BSA) & - & 66.3 \\
\hline Glutamic dehydrogenase & - & 55.4 \\
\hline Lactate dehydrogenase & - & 36.5 \\
\hline Carbonic anhydrase & - & 31.0 \\
\hline- & Triosephophate isomerase & 26.6 \\
\hline Trpsin inhibitor & - & 21.5 \\
\hline- & Myoglobin (from horse heart) & 17.0 \\
\hline Lysozyme & - & 14.4 \\
\hline- & a-lactalbumin (from bovine milk) & 14.2 \\
\hline- & Aprotinin (from bovine lung) & 6.5 \\
\hline Aprotinin & - & 6.0 \\
\hline Insulin B chain & Insulin B chain (oxidised bovine) & 3.5 \\
\hline Insulin A chain & - & 2.5 \\
\hline- & Bradykinin & 1.06 \\
\hline
\end{tabular}


Table 2 Tricine-SDS-PAGE protocol for the preparation of the polyacrylamide gels.

\begin{tabular}{|c|c|c|c|c|c|c|c|}
\hline \multicolumn{2}{|c|}{$\begin{array}{l}\text { Percentage of } \\
\text { Acrylamide in } \\
\text { the gel }\end{array}$} & $\begin{array}{c}\text { Acrylamide/bis- } \\
\text { acrylamide } 29: 1 \\
30 \% \text { solution } \\
(\mathrm{w} / \mathrm{v}) \\
\mathrm{mL}\end{array}$ & $\begin{array}{l}\text { Tris- } \\
\text { buffer } \\
\text { pH } 8.8 \\
\text { mL }\end{array}$ & $\begin{array}{l}\text { Deionized } \\
\text { Water } \\
\text { mL }\end{array}$ & $\mu \mathrm{L}$ & $\begin{array}{l}\text { APS } \\
30 \mathrm{mg} / \mathrm{mL} \\
\mu \mathrm{L}\end{array}$ & $\begin{array}{l}\text { Total } \\
\text { volume } \\
\sim \\
\mathrm{mL}\end{array}$ \\
\hline 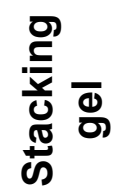 & 4 & 0.66 & 0.76 & 3.46 & 5.0 & 100 & 5 \\
\hline 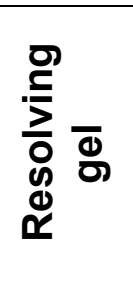 & $\begin{array}{l}7 \\
9 \\
10 \\
10.5 \\
15 \\
16\end{array}$ & $\begin{array}{l}2.33 \\
3.00 \\
3.33 \\
3.50 \\
5.00 \\
5.33\end{array}$ & $\begin{array}{l}5.60 \\
5.60 \\
5.60 \\
5.60 \\
4.60 \\
4.33\end{array}$ & $\begin{array}{l}1.91 \\
1.24 \\
0.96 \\
0.79 \\
0.29 \\
0.22\end{array}$ & $\begin{array}{l}7.0 \\
6.0 \\
6.0 \\
6.0 \\
6.0 \\
6.0\end{array}$ & $\begin{array}{l}150 \\
150 \\
100 \\
100 \\
100 \\
100\end{array}$ & $\begin{array}{l}10 \\
10 \\
10 \\
10 \\
10 \\
10\end{array}$ \\
\hline
\end{tabular}


Table 3 GE parameters for on-line coupling

\begin{tabular}{ll}
\hline Voltage & $80-90 \mathrm{~V}$ for initial separation and \\
& $135-150 \mathrm{~V}$ for elution \\
Running/Elution buffer & $25 \mathrm{mM}$ Tris, $25 \mathrm{mM}$ tricine and \\
& $0.05 \% \mathrm{SDS}$ \\
& $130 \mu \mathrm{L} \mathrm{\textrm {min } ^ { - 1 }}$ \\
Flow rate & $7.3 \mathrm{~cm}$ \\
Gel length & $1.0 \mathrm{~cm}$ \\
Gel ID & 8.8 \\
pH of the gel & Polyacrylamide \\
Gel material & $10,10.5$ and $15 \%$ \\
$\begin{array}{l}\text { Percentage of acrylamide } \\
\text { in separating gel }\end{array}$ & \\
Percentage of acrylamide & $4 \%$ \\
in stacking gel & \\
\hline
\end{tabular}




\begin{tabular}{ll}
\hline Instrument (ICP-MS) & Thermo Finnigan Element 2 XR, \\
& Bremen, Germany \\
Cones & Ni sampler and Ni Skimmer \\
Nebulizer & PFA micro flow LC (Elemental \\
& Scientific Omaha, USA) \\
Flow rate & $130 \mu \mathrm{L}$ min $^{-1}$ \\
Spray chamber & Cyclonic (Glass Expansion, \\
& Victoria Australia \\
Analyte & $31 \mathrm{P}$ \\
Magnet mass & 30.973 \\
Mass range & $30.968-30.978$ \\
Resolution & Medium \\
Gas flows & Cool $=15.5 \mathrm{Lmin}^{-1}$ \\
& Auxiliary $=0.88 \mathrm{Lmin}^{-1}$ \\
& Nebulizer $=1.102 \mathrm{Lmin}^{-1}$ \\
Forward Power & $1300 \mathrm{~W}$ \\
\hline
\end{tabular}


Table $5{ }^{31} \mathrm{P}$ peak area of the $\beta$-casein digested peptide bands using WGE-ICP-MS flow injection.

\begin{tabular}{lc}
\hline Peptide Band & ${ }^{31} \mathrm{P}$ Peak Area $\left(10^{3}\right)$ \\
& $(N=5)$ \\
\hline Blank gel & $50 \pm 2.0$ \\
$2.0 \mathrm{kDa}$ & $51 \pm 4.0$ \\
$4.0 \mathrm{kDa}$ & $49 \pm 2.3$ \\
$5-6.0 \mathrm{kDa}$ & $50 \pm 2.2$ \\
Phosphopeptides & $83 \pm 5.4$ \\
\hline
\end{tabular}




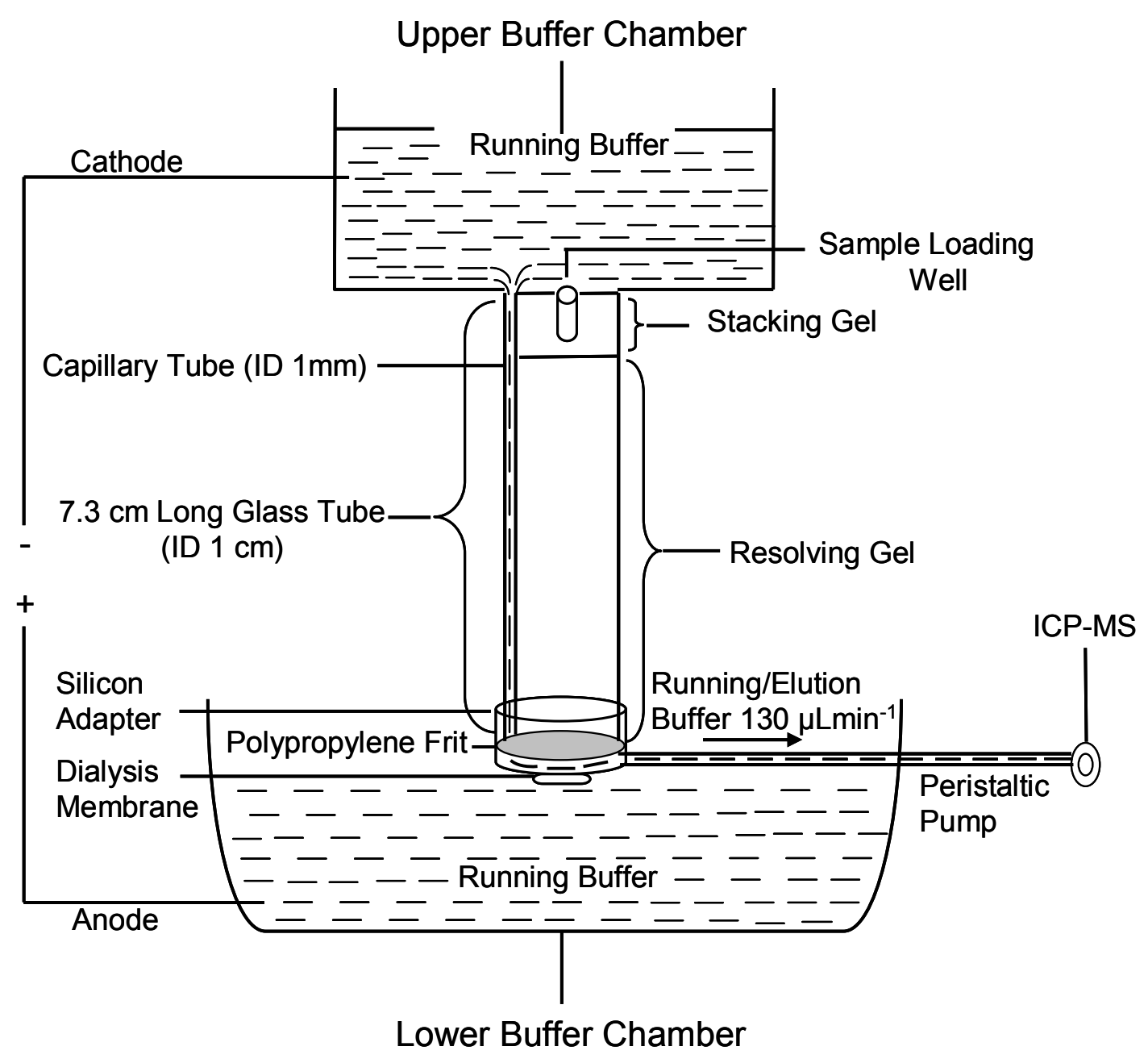

Fig. 1 Schematic diagram of GE-ICP-MS on-line coupling 

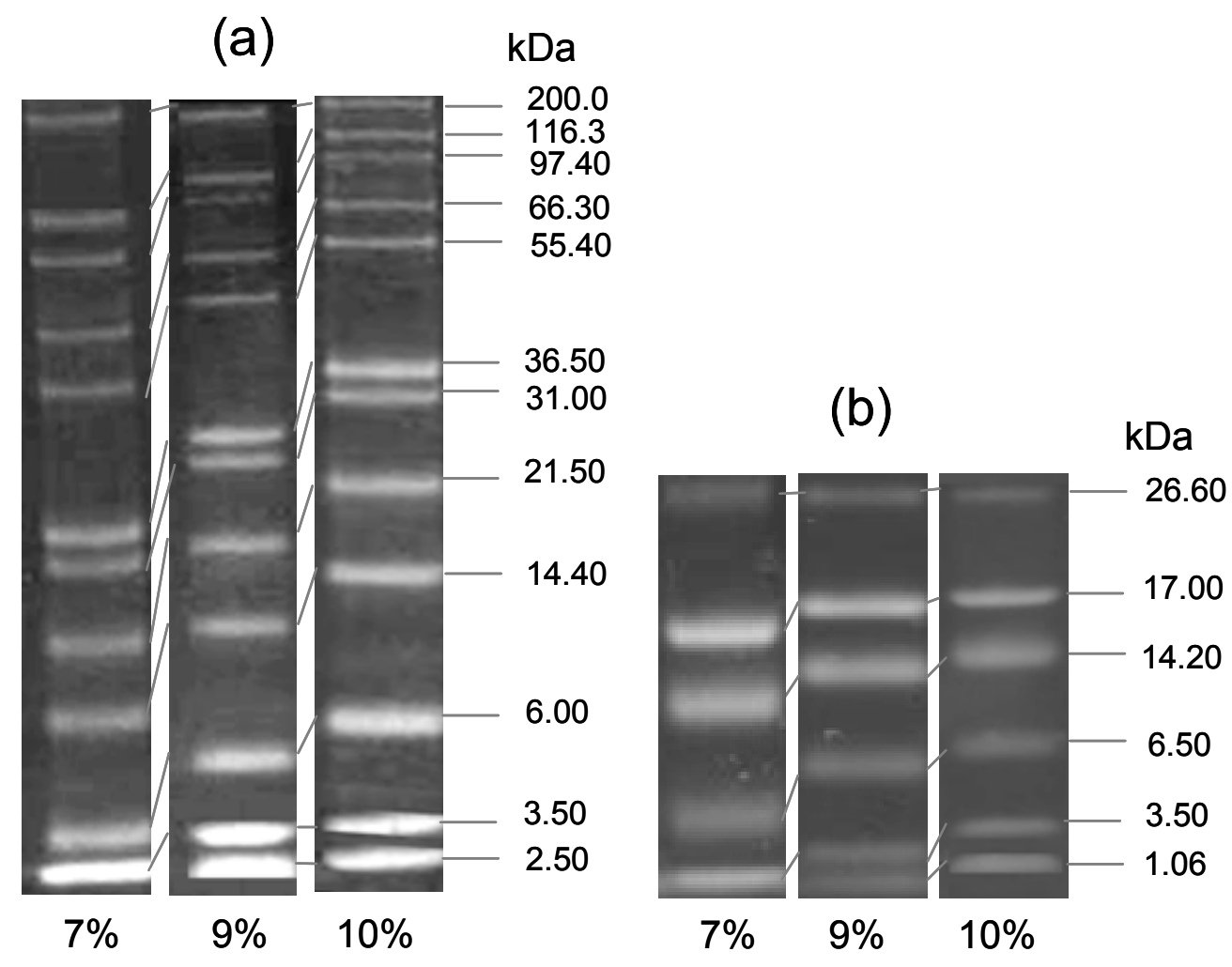

Fig. 2 Modified Tricine SDS-PAGE separation of low mass proteins in the range of (a) 2.5 to $200 \mathrm{kDa}$ (b) 1.0 to $26.6 \mathrm{kDa}$ in 7,9 and $10 \%$ gels. For proteins corresponding to the listed masses, see table 1. 


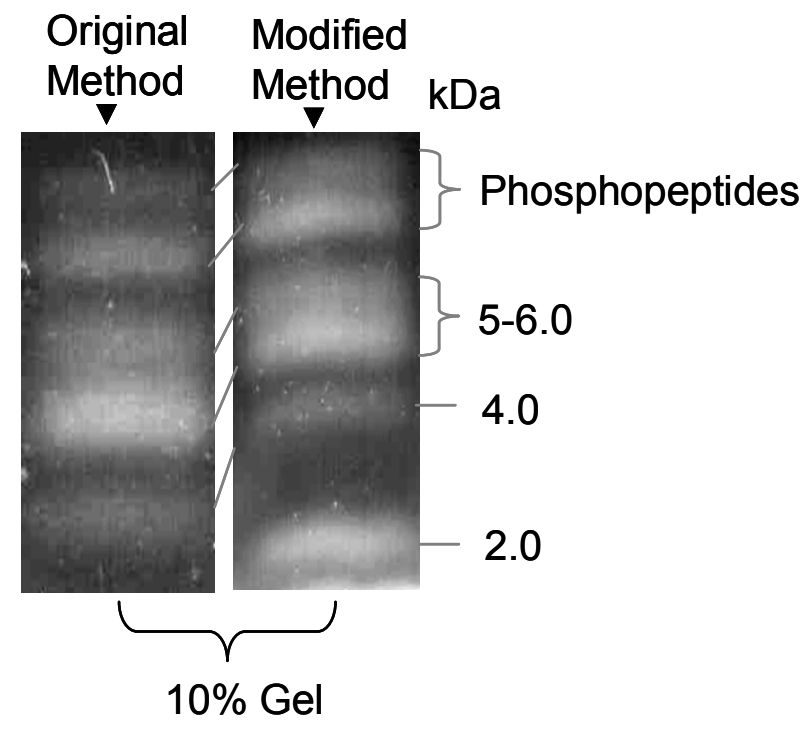

Fig. 3 Head to head comparative results for the $\beta$-casein digest using a $10 \%$ polyacrylamide slab gel with the original and modified Tricine-SDS-PAGE system. 

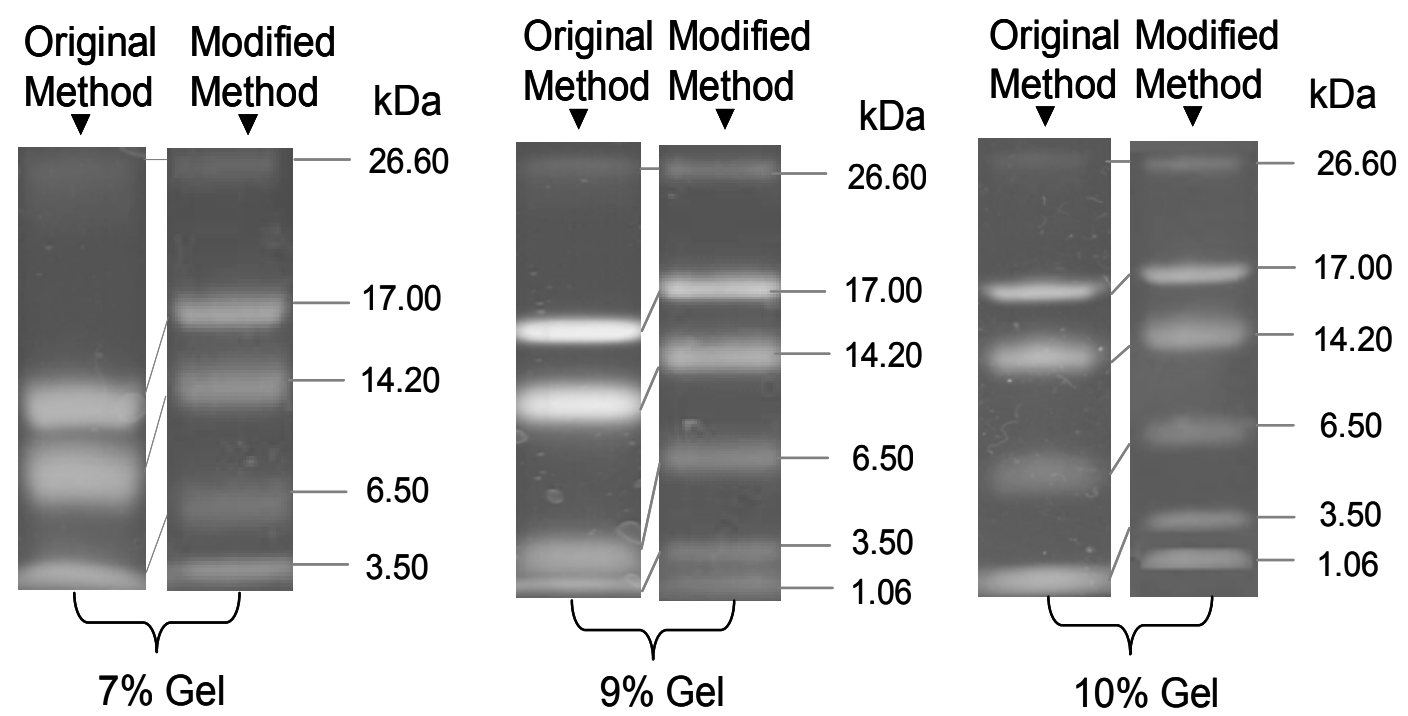

Fig. 4 By increasing the $\mathrm{pH}$ of the gel buffer an additional band was observed in 7, 9 and $10 \%$ modified gel. 


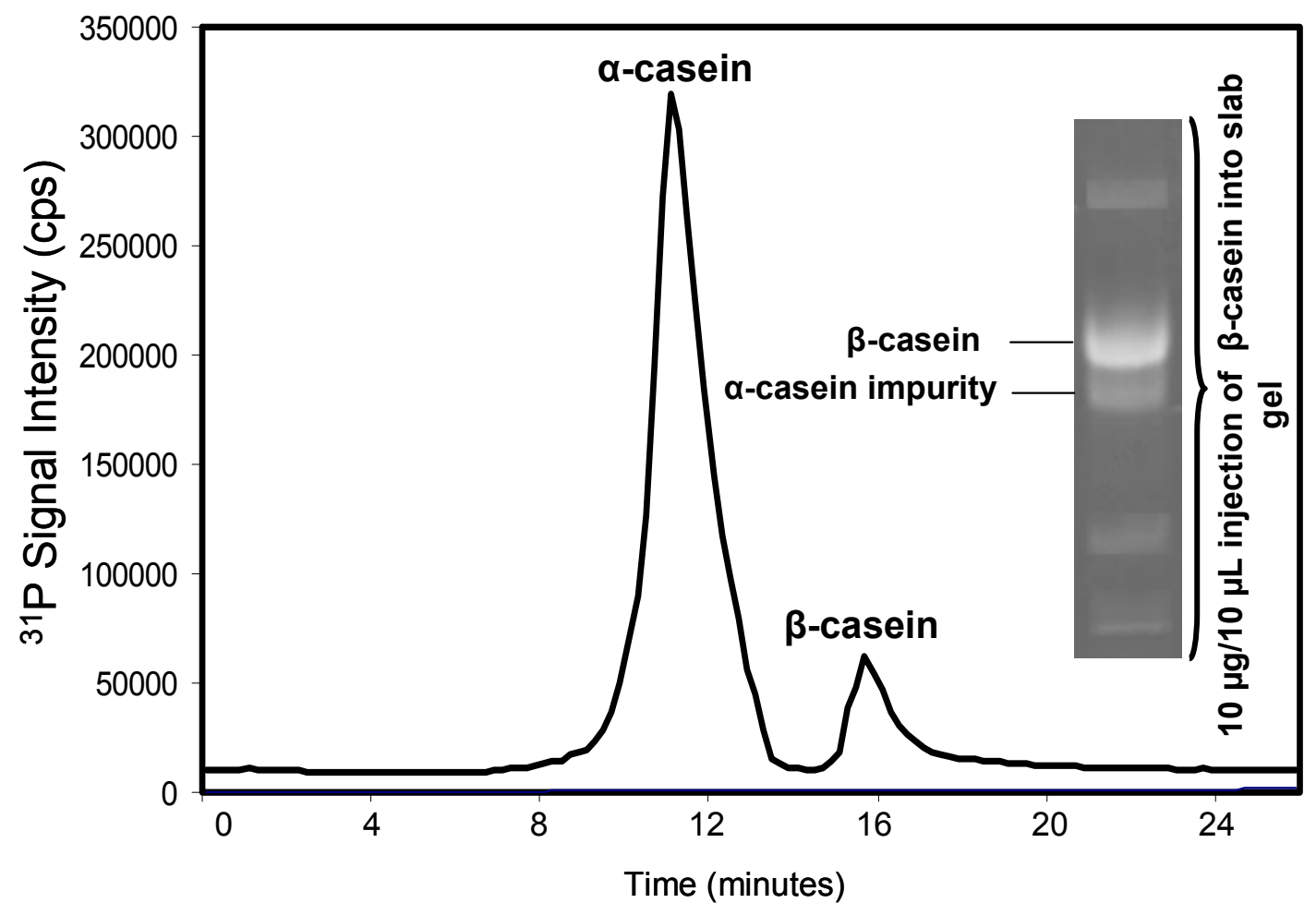

Fig. 5 GE-ICP-MS on-line separation for $\alpha$ - and $\beta$-casein. $10 \mu \mathrm{L}$ of the mixture of $0.10 \mathrm{nM} \alpha$ and $\beta$-casein was injected into $10 \%$ tube gel. $\beta$-casein was contaminated with $\alpha$-casein and some other proteins causing decrease in its signal intensity. $\beta$-casein impurities were also shown by injecting $10 \mu \mathrm{g} / 10 \mu \mathrm{L}$ in $10 \%$ slab gel. 


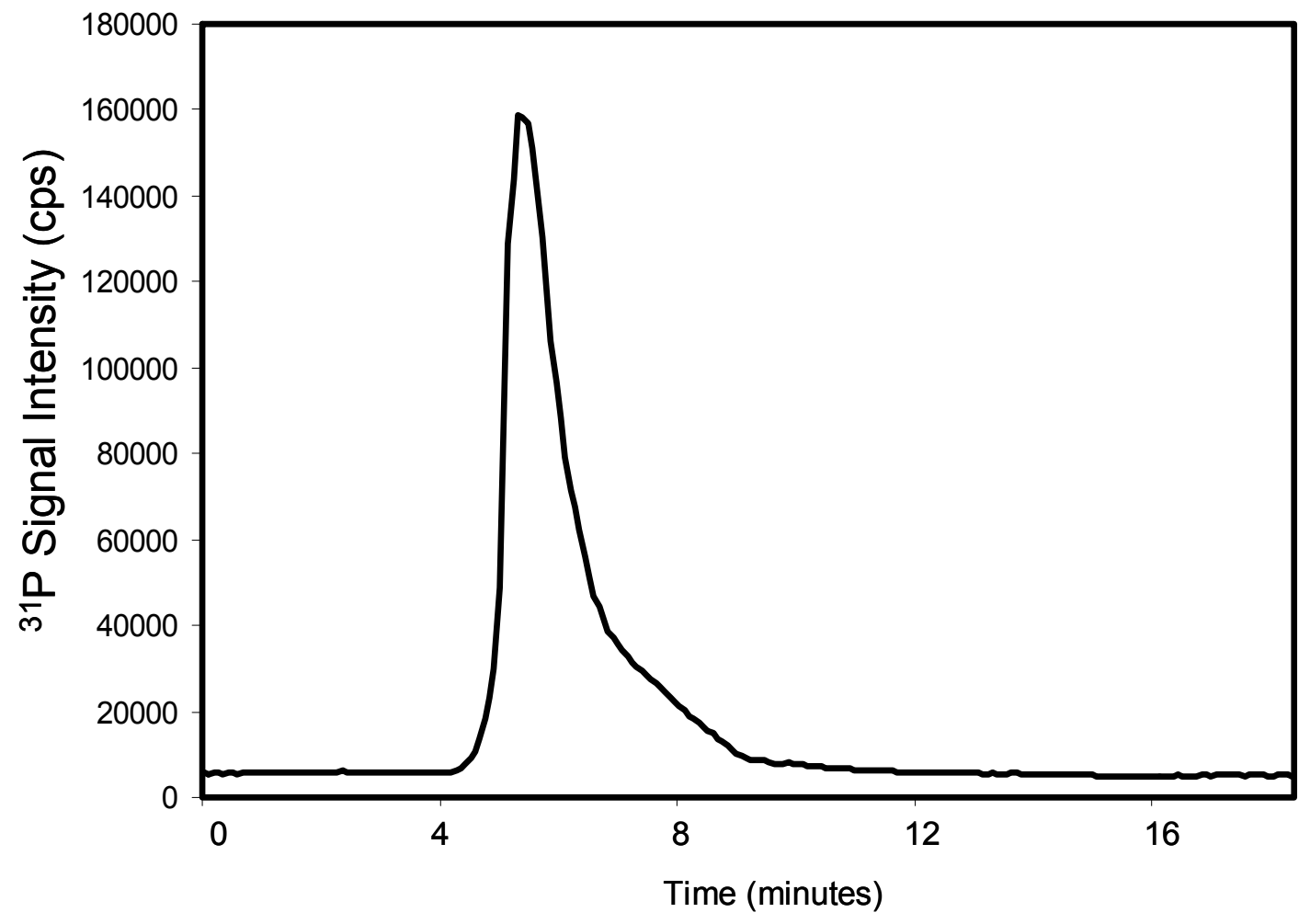

Fig. 6 Electropherogram for the $\beta$-casein digest. $10 \mu \mathrm{L}$ of the digest mixture of $\beta$-casein was injected into the $10 \%$ tube gel and only one peak was observed with a significant tailing. 


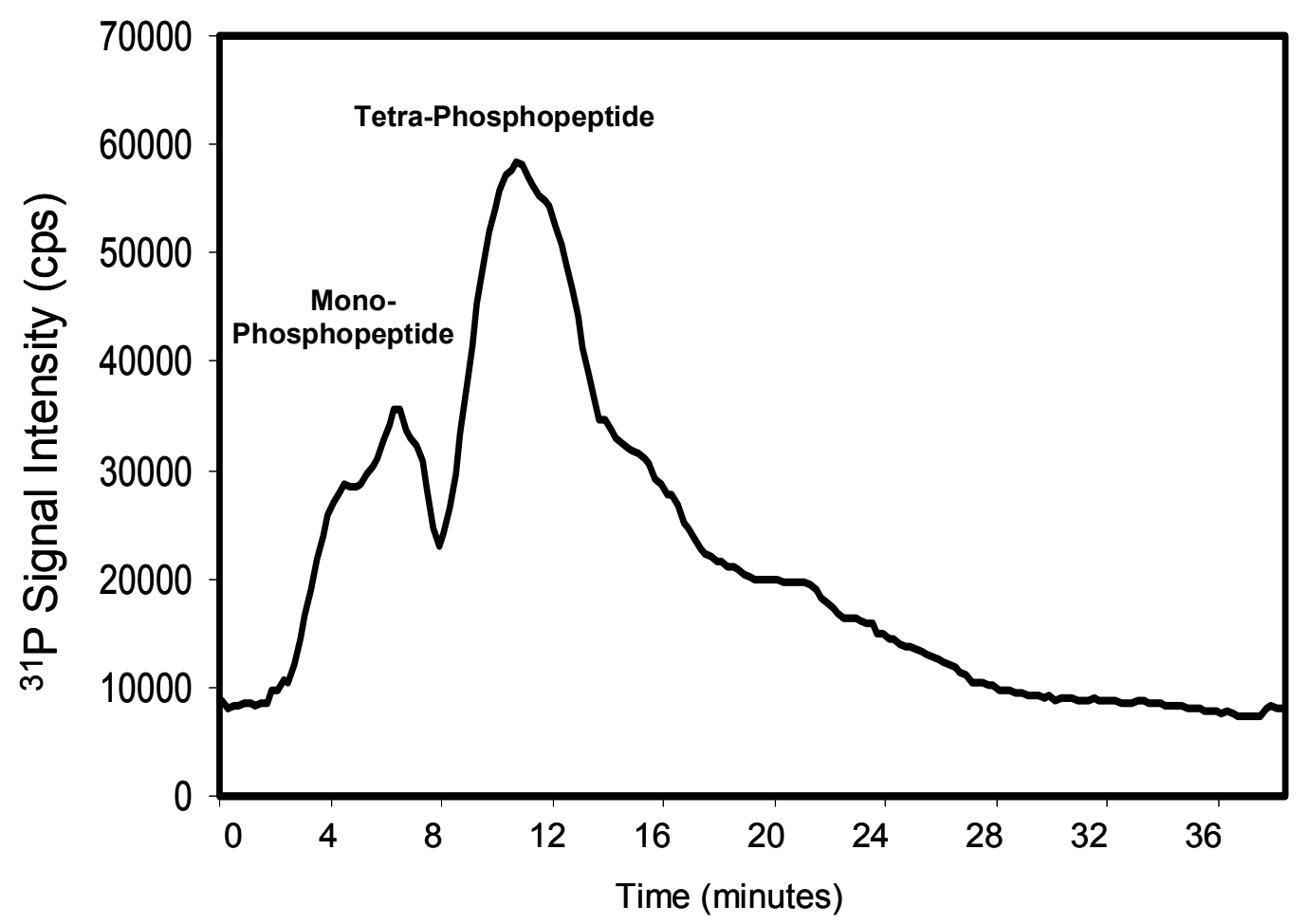

Fig. 7 GE-ICP-MS on-line separation of the peaks containing mono and tetra-phosphopeptide respectively from the digest mixture of $\beta$-casein. $10 \mu \mathrm{L}$ of the $\beta$-casein digest was injected into a $15 \%$ tube gel. 


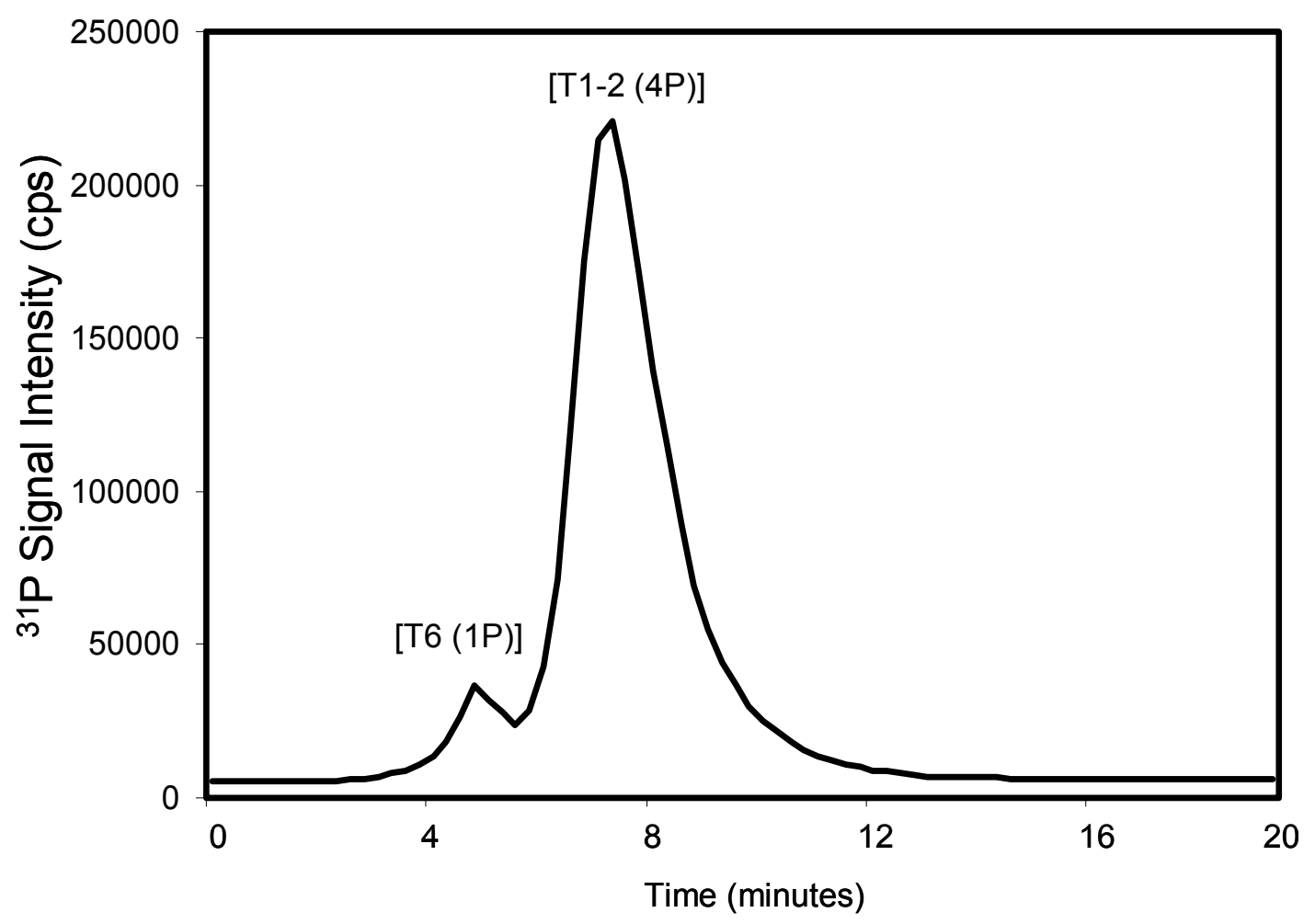

Fig. 8 GE-ICP-MS on-line separation of the mono and tetra-phosphopeptide standards. $10 \mu \mathrm{L}$ mixture of $20.2 \mu \mathrm{M}[\mathrm{T} 6(1 \mathrm{P})]$ and $16.34 \mu \mathrm{M}[\mathrm{T} 1-2$ (4P)] was injected into $10.5 \%$ tube gel. 